\title{
Pyrazinone protease inhibitor metabolites from Photorhabdus luminescens
}

\author{
Hyun Bong Park ${ }^{1,2}$ and Jason M Crawford ${ }^{1,2,3}$ \\ Photorhabdus luminescens is a bioluminescent entomopathogenic bacterium that undergoes phenotypic variation and lives in \\ mutualistic association with nematodes of the family Heterorhabditidae. The pair infects and kills insects, and during their \\ coordinated lifecycle, the bacteria produce an assortment of specialized metabolites to regulate its mutualistic and pathogenic \\ roles. As part of our search for new specialized metabolites from the Photorhabdus genus, we examined organic extracts from \\ $P$. luminescens grown in an amino-acid-rich medium based on the free amino-acid levels found in the circulatory fluid of its \\ common insect prey, the Galleria mellonella larva. Reversed-phase HPLC/UV/MS-guided fractionation of the culture extracts led \\ to the identification of two new pyrazinone metabolites, lumizinones A (1) and B (2), together with two $N$-acetyl dipeptides \\ ( 3 and 4). The lumizinones were produced only in the phenotypic variant associated with nematode development and insect \\ pathogenesis. Their chemical structures were elucidated by analysis of 1D and 2D NMR and high-resolution ESI-QTOF-MS \\ spectral data. The absolute configurations of the amino acids in 3 and 4 were determined by Marfey's analysis. Compounds 1-4 \\ were evaluated for their calpain protease inhibitory activity, and lumizinone A (1) showed inhibition with an $\mathrm{IC}_{50}$ (half-maximal \\ inhibitory concentration) value of $3.9 \mu \mathrm{m}$. \\ The Journal of Antibiotics (2016) 69, 616-621; doi:10.1038/ja.2016.79; published online 29 June 2016
}

\section{INTRODUCTION}

Chemical investigations of bacterial symbionts associated with eukaryotic hosts have yielded structurally and functionally diverse small molecules that have pivotal roles in regulating host-bacteria interactions. The insect pathogenic (entomopathogenic) bacteria of the Photorhabdus genus have emerged as one such prolific source of novel bioactive metabolites. ${ }^{1-3}$ These bacteria engage in a mutualistic symbiosis with the entomopathogenic nematodes of the family Heterorhabditidiae. ${ }^{4,5}$ Infective juvenile nematodes carry Photorhabdus in their intestinal tracts, penetrate susceptible insect larvae in the soil and regurgitate Photorhabdus in the insect circulatory fluid (hemolymph). The bacteria stochastically switch between two major phenotypic variants, the mutualistic M-form associated with colonization of the nematode and the pathogenic P-form associated with producing diverse cytotoxins, nematode development signals, innate immunomodulators and anti-microbials. ${ }^{6}$ During infection and insect consumption, the bacteria exponentially proliferate, the nematodes consume the resulting bacterial biomass and the insect dies from septicemia. The nematodes proceed through their developmental cycle, and ultimately, newly formed infective juveniles emerge from the insect carcass and hunt for new insect larval prey.

Of the growing number of bioactive small molecules identified from the Photorhabdus genus, several have been shown to regulate key biological functions associated with the complex tripartite bacteria-nematode-insect relationship. ${ }^{1-3}$ For example, a variety of multipotent stilbene metabolites have been identified from Photorhabdus species, which serve as nematode development signals, invertebrate innate immunosuppressants and anti-microbial defense compounds against microbial competitors. ${ }^{7-9}$ Additionally, a tyrosinederived virulence factor, rhabduscin, containing an isonitrile functional group displayed potent inhibitory activity against phenoloxidase, an enzyme known to be a crucial component of the insect's innate immune system, and was required for virulence at physiologically relevant inocula. ${ }^{10}$ Indeed, genomic analyses of individual Photorhabdus species indicate a much larger number of biosynthetic gene clusters, many of which have not been characterized to date. ${ }^{1-3}$

As part of our efforts to discover new bioactive small molecules from bacterial symbionts, here we focused on the strain Photorhabdus luminescens TT01 grown in a hemolymph-mimetic bacterial culture medium. The medium was based on the remarkably high concentrations of the 20 free proteinogenic amino acids $\left(35.01 \mathrm{gl}^{-1}\right.$ of free amino acids) in the hemolymph of their larval host Galleria mellonella. ${ }^{11}$ Through HPLC/UV/MS-guided fractionation, NMRbased structural elucidation and HR-ESI-QTOF-MS analysis, we characterized the chemical structures of two previously unknown bacterial pyrazinone metabolites, which we named lumizinones A (1) and B (2), together with two linear $N$-acetyl dipeptides (3 and 4). Here, we describe their isolation from the P-form phenotypic variant

${ }^{1}$ Department of Chemistry, Yale University, New Haven, CT, USA; ${ }^{2}$ Chemical Biology Institute, Yale University, West Haven, CT, USA and ${ }^{3}$ Department of Microbial Pathogenesis, Yale School of Medicine, New Haven, CT, USA

Correspondence: Professor JM Crawford, Department of Chemistry and Microbial Pathogenesis, Yale University, PO BOX 27392, West Haven, CT 06516, USA.

E-mail: jason.crawford@yale.edu

This article is dedicated to the fond memory of the late Professor Lester Mitscher, a great scholar, teacher and Emeritus Editor of this Journal.

Received 16 March 2016; Revised 6 June 2016; accepted 6 June 2016; published online 29 June 2016 
of $P$. luminescens, their structure elucidation and their in vitro calpain protease inhibitory activity.

\section{RESULTS AND DISCUSSION}

$P$. luminescens subsp. laumondii strain $\mathrm{TT} 01^{12}$ was cultivated on Luria-Bertani agar plate at $30^{\circ} \mathrm{C}$ for $48 \mathrm{~h}$. A single colony was inoculated into $5 \mathrm{ml}$ of the hemolymph-mimetic bacterial growth medium and then incubated at $30^{\circ} \mathrm{C}$ on a rotary shaker (250 r.p.m.). After 2 days, the culture broth was centrifuged (3000 r.p.m., 15 min), the supernatant was extracted with $10 \mathrm{ml}$ of ethyl acetate and the organic layer was dried under reduced pressure. Crude ethyl acetatesoluble materials were analyzed by $\mathrm{C}_{18}$ HPLC connected to a lowresolution ESI-MS system. HPLC/UV/MS data analysis displayed the presence of two distinct peaks 1 and 2, eluting at $t_{\mathrm{R}} 14.29 \mathrm{~min}\left([\mathrm{M}+\mathrm{H}]^{+}\right.$ $\mathrm{m} / z$ 259) and $t_{\mathrm{R}} 15.48 \mathrm{~min}\left([\mathrm{M}+\mathrm{H}]^{+} \mathrm{m} / \mathrm{z} 293\right)$, respectively (Figure 1$)$. The peaks shared a similar UV absorption spectrum with $\lambda_{\max }$ of 220 , 280 and $330 \mathrm{~nm}$, suggesting the presence of a pyrazinone-type chromophore (Supplementary Figure S1). ${ }^{13}$ To further characterize

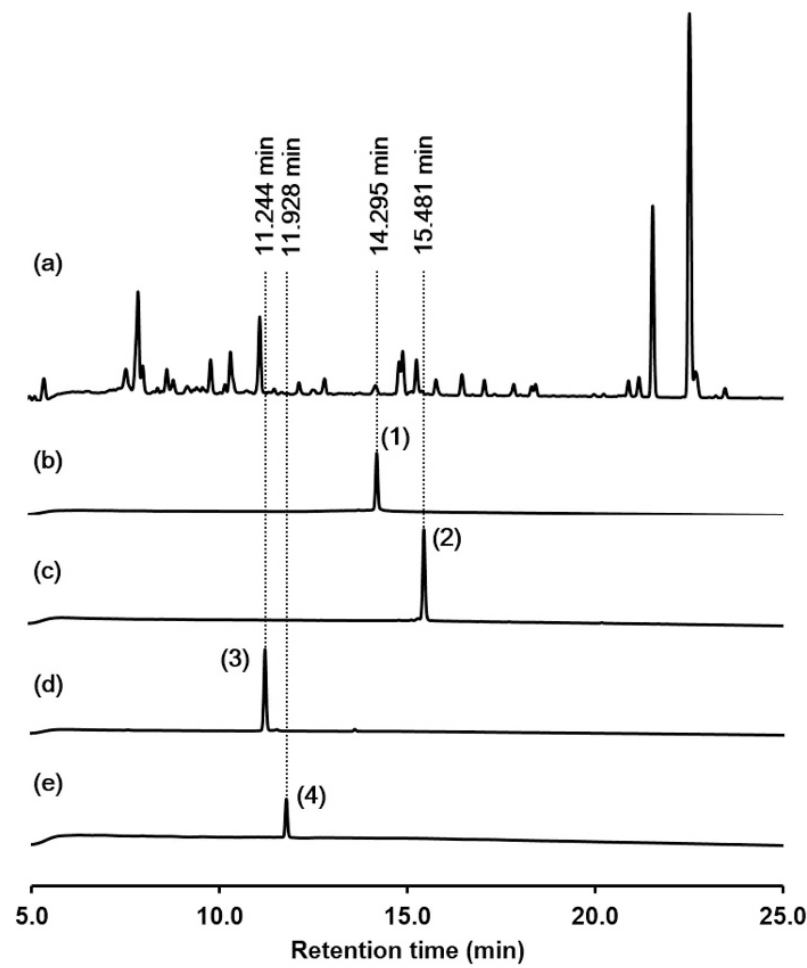

Figure 1 Detection of compounds $\mathbf{1 - 4}$ from organic extracts of $P$. luminescens TT01. UV traces of crude extracts (a) and compounds 1-4 (b-e) were monitored at $210 \mathrm{~nm}$. the two metabolites, a $12 \mathrm{~L}$ scale aerobic cultivation of $P$. luminescens TT01 was initiated in the same medium at $30^{\circ} \mathrm{C}$ for $48 \mathrm{~h}$, and the whole culture was extracted two times with equal volumes of ethyl acetate (total $24 \mathrm{~L}$ ). The organic fraction was dried in vacuo to yield $2.0 \mathrm{~g}$ of crude material. The ethyl acetate extract $(2.0 \mathrm{~g})$ was subjected to silica flash column chromatography using a hexane-ethyl acetate-methanol solvent composition followed by reversed-phase HPLC purification, which yielded pure compounds 1 (2.2 mg, lumizinone A) and 2 (1.5 mg, lumizinone B) (Figure 2).

Lumizinone A (1) was isolated as a colorless solid. The molecular formula was determined to be $\mathrm{C}_{15} \mathrm{H}_{18} \mathrm{~N}_{2} \mathrm{O}_{2}$ (obsd $[\mathrm{M}+\mathrm{H}]^{+} \mathrm{m} / \mathrm{z}$ 259.1447, calcd 259.1447) based on HR-ESI-QTOF-MS data, indicating that the chemical structure of 1 contains $8^{\circ}$ of unsaturation (Supplementary Figure S2). The NMR-based structural characterization was achieved by the interpretation of ${ }^{1} \mathrm{H}$ and $2 \mathrm{D}$ spectral data (gCOSY, gHSQC and gHMBC) (Supplementary Figures S3-S6). Briefly, the ${ }^{1} \mathrm{H}$ NMR spectrum of 1 recorded in methanol- $d_{4}$ displayed characteristics of two aromatic resonances $\left(\delta_{\mathrm{H}} 7.06(2 \mathrm{H}, \mathrm{m}), 6.74\right.$ $(2 \mathrm{H}, \mathrm{m}))$, an olefinic methine proton $\left(\delta_{\mathrm{H}} 7.04(1 \mathrm{H}\right.$, brs $\left.)\right)$, two methylene signals $\left(\delta_{\mathrm{H}} 3.73(2 \mathrm{H}, \mathrm{s}), 2.56(2 \mathrm{H}, \mathrm{d}, J=7.2 \mathrm{~Hz})\right)$, a methine proton $\left(\delta_{\mathrm{H}} 2.13(1 \mathrm{H}, \mathrm{m})\right)$ and a doublet methyl signal $\left(\delta_{\mathrm{H}}\right.$ $0.91(6 \mathrm{H}, \mathrm{d}, J=6.7 \mathrm{~Hz})$ ) (Table 1). The HSQC spectrum of 1 indicated that all of the protons were directly bonded to carbons. The COSY cross-peaks between $\mathrm{H}-9 / \mathrm{H}-13\left(\delta_{\mathrm{H}} 7.06\right)$ and $\mathrm{H}-10 / 12\left(\delta_{\mathrm{H}} 6.74\right)$ along with proton coupling constant $(J=8.5 \mathrm{~Hz})$ suggested the presence of a para-substituted benzene ring and a long-range COSY correlation from $\mathrm{H}-9 / \mathrm{H}-13\left(\delta_{\mathrm{H}} 7.06\right)$ to a singlet methylene $\mathrm{H}-7\left(\delta_{\mathrm{H}} 3.73\right)$ allowed us to establish a benzyl moiety. Subsequently, observed COSY correlations from doublet methyl protons $\mathrm{H}-3^{\prime} / \mathrm{H}-4^{\prime}\left(\delta_{\mathrm{H}} 0.91\right)$ to an aliphatic methylene proton $\mathrm{H}-1^{\prime}\left(\delta_{\mathrm{H}} 2.56\right)$ also supported construction of an isobutyl partial structure. The presence of two partial structures were further supported by the analysis of $\mathrm{HMBC}$ NMR spectral data. The HMBC correlations from $\mathrm{H}-9 / \mathrm{H}-13\left(\delta_{\mathrm{H}} 7.06\right)$ to a hydroxylated aromatic carbon signal C-11 $\left(\delta_{\mathrm{C}} 156.3\right)$ and a methylene carbon C-7 $\left(\delta_{\mathrm{C}} 34.7\right)$, and from $\mathrm{H}-10 / \mathrm{H}-12\left(\delta_{\mathrm{H}} 6.74\right)$ to a quaternary carbon C-8 $\left(\delta_{\mathrm{C}} 126.8\right)$ established a para-hydroxybenzyl group. The other isobutyl partial structure was determined by the additional HMBC correlations from $\mathrm{H}-3^{\prime} / \mathrm{H}-4^{\prime}\left(\delta_{\mathrm{H}} 0.91\right)$ to $\mathrm{C}-1^{\prime}\left(\delta_{\mathrm{C}} 41.0\right)$. Construction of the pyrazinone ring was achieved by the $\mathrm{HMBC}$ correlations from $\mathrm{H}-1^{\prime}$ $\left(\delta_{\mathrm{H}} 2.56\right)$ to an amide carbonyl C-2 $\left(\delta_{\mathrm{C}} 156.8\right)$ and from a singlet methylene proton $\mathrm{H}-7 \quad\left(\delta_{\mathrm{H}} 3.73\right)$ to a quaternary carbon C-6 $\left(\delta_{\mathrm{C}} 139.3\right)$ and an olefinic methine carbon $\mathrm{C}-5\left(\delta_{\mathrm{C}} 121.4\right)$. Finally, the $\mathrm{HMBC}$ correlations from an olefinic methine $\mathrm{H}-5\left(\delta_{\mathrm{H}} 7.04\right)$ to C-7 $\left(\delta_{\mathrm{C}} 34.7\right)$ and C-3 $\left(\delta_{\mathrm{C}} 156.7\right)$ unambiguously constructed the $2(1 H)$ pyrazinone substituted with a para-hydroxybenzyl moiety and an isobutyl group at C-6 and C-3, respectively (Figure 3). Additionally, the structures were further supported by comparison with previously<smiles>CC(C)Cc1ncc(Cc2ccc(O)cc2)[nH]c1=O</smiles>

(1)<smiles>O=c1[nH]c(Cc2ccc(O)cc2)cnc1Cc1ccccc1</smiles>

(2)<smiles>CSCC[C@H](NC(=O)[C@H](CC(C)C)NC(C)=O)C(=O)O</smiles>

(3)
(4)

Figure 2 Chemical structures of compounds 1-4. 
Table $1{ }^{1} \mathrm{H}$ and ${ }^{13} \mathrm{C}$ NMR spectral data of lumizinone $A(1)$ and $B(2)$ in $\mathrm{CD}_{3} \mathrm{OD}$

\begin{tabular}{|c|c|c|c|c|c|c|c|c|}
\hline \multirow[b]{2}{*}{ No. } & \multicolumn{4}{|c|}{ Lumizinone A (1) } & \multicolumn{4}{|c|}{ Lumizinone B (2) } \\
\hline & $\delta C^{\mathrm{b}}$ & Type & $\delta_{H^{c}}$ & Mult (J in Hz) & $\delta c^{\mathrm{b}}$ & Type & $\delta_{H^{c}}^{c}$ & Mult (J in Hz) \\
\hline 1 & & $\mathrm{NH}$ & & & & $\mathrm{NH}$ & & \\
\hline 2 & 156.8 & $\mathrm{C}$ & & & 156.5 & $\mathrm{C}$ & & \\
\hline 3 & 156.7 & C & & & 155.8 & C & & \\
\hline 4 & & $\mathrm{~N}$ & & & & $\mathrm{~N}$ & & \\
\hline 5 & 121.4 & $\mathrm{CH}$ & 7.04 & br s & 121.4 & $\mathrm{CH}$ & 7.04 & br s \\
\hline 6 & 139.4 & $\mathrm{C}$ & & & 139.7 & $\mathrm{C}$ & & \\
\hline 7 & 34.7 & $\mathrm{CH}_{2}$ & 3.73 & $\mathrm{~s}$ & 34.6 & $\mathrm{CH}_{2}$ & 3.72 & $\mathrm{~s}$ \\
\hline 8 & 126.8 & $c$ & & & 126.7 & $C$ & & \\
\hline 9 & 129.5 & $\mathrm{CH}$ & 7.06 & $\mathrm{~m}$ & 129.5 & $\mathrm{CH}$ & 7.05 & $\mathrm{~m}$ \\
\hline 10 & 115.1 & $\mathrm{CH}$ & 6.74 & $\mathrm{~m}$ & 115.1 & $\mathrm{CH}$ & 6.72 & $\mathrm{~m}$ \\
\hline 11 & 156.3 & $C$ & & & 156.2 & $\mathrm{C}$ & & \\
\hline 12 & 115.1 & $\mathrm{CH}$ & 6.74 & $\mathrm{~m}$ & 115.1 & $\mathrm{CH}$ & 6.72 & $\mathrm{~m}$ \\
\hline 13 & 129.5 & $\mathrm{CH}$ & 7.06 & m & 129.5 & $\mathrm{CH}$ & 7.05 & $\mathrm{~m}$ \\
\hline $1^{\prime}$ & 41.0 & $\mathrm{CH}_{2}$ & 2.56 & $\mathrm{~d}(7.2 \mathrm{~Hz})$ & 38.2 & $\mathrm{CH}_{2}$ & 3.99 & $\mathrm{~s}$ \\
\hline $2^{\prime}$ & 26.5 & $\mathrm{CH}$ & 2.13 & m & 137.5 & $\mathrm{C}$ & & \\
\hline $3^{\prime}$ & 21.4 & $\mathrm{CH}_{3}$ & 0.91 & $\mathrm{~d}(6.7 \mathrm{~Hz})$ & 128.6 & $\mathrm{CH}$ & 7.27 & $\mathrm{~d}(7.5 \mathrm{~Hz})$ \\
\hline $4^{\prime}$ & 21.4 & $\mathrm{CH}_{3}$ & 0.91 & $\mathrm{~d}(6.7 \mathrm{~Hz})$ & 127.8 & $\mathrm{CH}$ & 7.23 & $\mathrm{t}(7.5 \mathrm{~Hz})$ \\
\hline $5^{\prime}$ & & & & & 125.9 & $\mathrm{CH}$ & 7.15 & $\mathrm{t}(7.2 \mathrm{~Hz})$ \\
\hline $6^{\prime}$ & & & & & 127.8 & $\mathrm{CH}$ & 7.23 & $\mathrm{t}(7.5 \mathrm{~Hz})$ \\
\hline $7^{\prime}$ & & & & & 128.6 & $\mathrm{CH}$ & 7.27 & $\mathrm{~d}(7.5 \mathrm{~Hz})$ \\
\hline
\end{tabular}

a Methanol- $d_{4}\left(\delta_{\mathrm{H}} 3.29, \delta_{\mathrm{C}} 47.7\right)$.

${ }^{\mathrm{b}}$ Chemical shifts of ${ }^{13} \mathrm{C}$ were determined by HSQC and HMBC.

cSix hundred megahertz for ${ }^{1} \mathrm{H}$ NMR data.

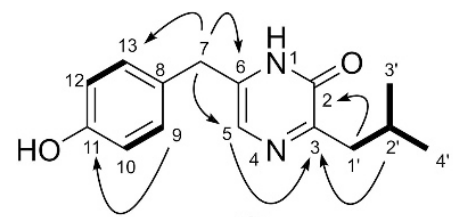

(1)

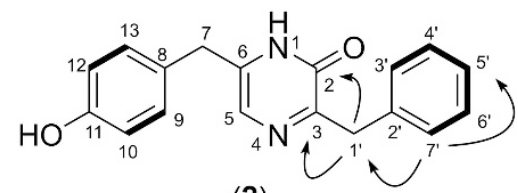

(2)

Figure 3 Key COSY (bold) and HMBC (arrow) correlations of compounds 1 and 2.

reported ${ }^{1} \mathrm{H}$ and ${ }^{13} \mathrm{C}$ chemical shifts of other 3,6-disubstituted pyrazinones. ${ }^{14}$ Therefore, the structure of 1 was assigned as 6-(4-hydroxybenzyl)-3-isobutylpyrazin-2(1H)-one.

Lumizinone B (2) was also isolated as a colorless solid. The molecular formula was determined to be $\mathrm{C}_{18} \mathrm{H}_{16} \mathrm{~N}_{2} \mathrm{O}_{2}$ (obsd $[\mathrm{M}+\mathrm{H}]^{+}$ $m / z$ 293.1286, calcd 293.1290) based on HR-ESI-QTOF-MS data, indicating that the chemical structure of 2 contains $12^{\circ}$ of unsaturation (Supplementary Figure S2). Similar to $1,{ }^{1} \mathrm{H}$ NMR suggested the presence of a para-hydroxybenzyl ring; however, the constitution of an additional benzyl ring was supported instead of the isobutyl group in $\mathbf{1}$ (Supplementary Figure S7). The gross structure of $\mathbf{2}$ was established by analysis of the COSY and HMBC spectral data (Supplementary Figures S8-S10). COSY correlations from $\mathrm{H}-3^{\prime} / \mathrm{H}-7^{\prime}\left(\delta_{\mathrm{H}} 7.27\right)$ to $\mathrm{H}-5^{\prime}$ $\left(\delta_{\mathrm{H}} 7.15\right)$ and a singlet methylene proton $\mathrm{H}-1^{\prime}\left(\delta_{\mathrm{H}} 3.99\right)$ supported the presence of the benzyl ring system, which was confirmed by HMBC correlations. Finally, the HMBC correlation from H-1' $\left(\delta_{\mathrm{H}} 3.99\right)$ to C-2 $\left(\delta_{\mathrm{C}} 156.5\right)$ allowed the substitution of the benzyl group at C-3 (Figure 3 ). Therefore, the structure of 2 was assigned as 3-benzyl6-(4-hydroxybenzyl)pyrazin-2(1H)-one.

Because wild-type P. luminescens uses an invertible promoter switch to stochastically regulate formation of the $\mathrm{M}$ - and P-form phenotypic variants, we assessed lumizinone production in two genetically engineered strains of $P$. luminescens where the promoter was locked in an ON (M-form) or OFF (P-form) orientation. ${ }^{6}$ Lumizinone production was only detected in the pathogenic P-form phenotypic variant, unambiguously establishing the cellular state for the production of these metabolites (Figure 4).

In the course of isolating lumizinones A (1) and B (2), two compounds $\mathbf{3}$ and $\mathbf{4}$ were also isolated and identified by the analysis of NMR and HR-ESI-QTOF-MS spectral data (Supplementary Figures S11-S17). Examination of the ${ }^{1} \mathrm{H}$ and 2D NMR (gCOSY and gHMBC) of 3 and 4 combined with Marfey's analysis unambiguously allowed for their structures to be assigned as $\mathrm{N}$-acetyl-L-leucyl-L-tyrosine (3) and $N$-acetyl-L-leucyl-L-methionine (4), respectively. The connectivity of an $\mathrm{N}$-acetyl group was established by two- and three-bond longrange HMBC correlations toward a carbonyl carbon from each $\alpha$-proton in the leucine amino-acid and methyl protons in the acetyl group, and the absolute configurations of amino-acid constituents in compounds 3 and $\mathbf{4}$ were determined by Marfey's analysis (Supplementary Figure S18). ${ }^{15}$ These compounds have previously been described as hydrolytic peptide products of the carboxypeptidase enzyme. ${ }^{16}$

Many natural products derived from microorganisms share a 3,6disubstituted 2(1H)-pyrazinone core, most of which are classified by constitution of different amino-acid residues, such as valine-tyrosine (tyrvalin), valine-phenylalanine (phevalin) and valine-leucine (leuvalin) metabolites. ${ }^{17}$ The lumizinones isolated from $P$. luminescens are structurally distinct from other 3,6-disubstituted 2(1H)-pyrazinone metabolites, in which they are derived from a combination of tyrosineleucine (1) or tyrosine-phenylalanine (2). The representative cyclic dipeptide phevaline was originally isolated from a terrestrial Streptomyces sp. in the course of activity-based screening for protease inhibitors. ${ }^{14}$ Interestingly, aureusimine metabolites including phevaline (aureusimine B) were also isolated from the human pathogen Staphylococcus aureus. ${ }^{18}$ More recently, it has been reported that phevaline may have a potential role in S. aureus biofilm formation. ${ }^{19}$ Consequently, we also screened the metabolite profile of the dual insect-human pathogen Photorhabdus asymbiotica. However, lumizinone metabolites ( $\mathbf{1}$ and $\mathbf{2}$ ) were not detected under the conditions of our experiment (Supplementary Figure S19). Nor could a homolog of the central aureusimine nonribosomal peptide synthetase be identified in the reported genomes of $P$. luminescens TT01 or P. asymbiotica. ${ }^{20,21}$ It is currently unclear how the lumizinones are biosynthesized in P. luminescens.

Previously, phevaline was shown to harbor calpain protease inhibitory activity (half-maximal inhibitory concentration $\left(\mathrm{IC}_{50}=1.3 \mu \mathrm{M}\right) .{ }^{14}$ Calpains are a $\mathrm{Ca}^{2+}$-dependent family of intracellular cysteine proteases that are widely distributed in eukaryotic cells and tissues. ${ }^{22,23}$ Calpain is a cytoplasmic heterodimer composed of a catalytic subunit $(80 \mathrm{kDa})$ and a regulatory subunit $(30 \mathrm{kDa})$. Calpain 1 ( $\mu$-calpain) and calpain 2 (m-calpain), two representative calpain isoforms, are activated by micromolar and millimolar $\mathrm{Ca}^{2+}$ concentrations within the cells, respectively. Calpains have crucial roles in numerous physiological and pathological process in the cells. For example, calpains catalyze the hydrolysis of a variety of substrate proteins that are associated with physiological processes, such as signal 


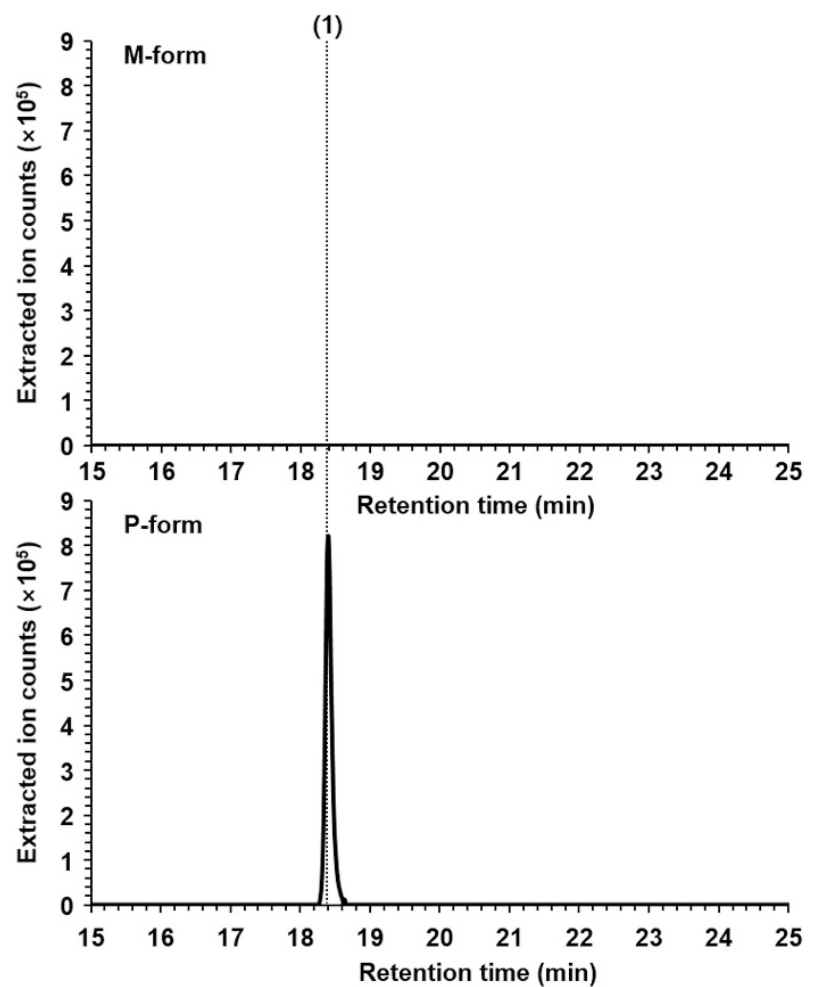

Figure 4 Extracted ion counts chromatograms of lumizinones A (1) and B phenotypic M-form and P-form.

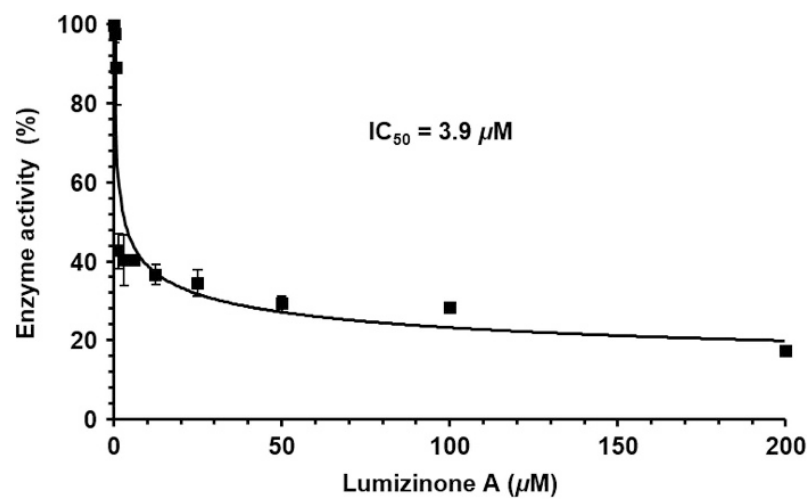

Figure 5 Calpain protease inhibitory activity of lumizinone A (1).

transduction, cell proliferation and differentiation, apoptosis, membrane fusion and platelet activation. However, hyperactivation of calpains by elevation of $\mathrm{Ca}^{2+}$ concentration could lead to various pathological processes including ischemia, brain injury, cancer and neurological disorders such as Alzheimer's disease. ${ }^{24}$ Owing to the known calpain inhibitory activity of phevaline, the inhibitory activities of compounds 1-4 against calpain protease were evaluated in an established luminescence assay. Lumizinone A (1) displayed an inhibitory effect against calpain with an $\mathrm{IC}_{50}$ value of $3.9 \mu \mathrm{M}$ (Figure 5), whereas compounds 2-4 were not active in this assay $\left(\mathrm{IC}_{50}>100.0 \mu \mathrm{M}\right)$. Cysteine proteases have been implicated in the activation of the nuclear factor- $\kappa \mathrm{B}$ inflammatory signaling pathway in the model invertebrate Drosophila melanogaster. ${ }^{25}$ While we speculate that such cysteine protease inhibition could serve an immunomodulatory role during insect pathogenesis, which could be supported by

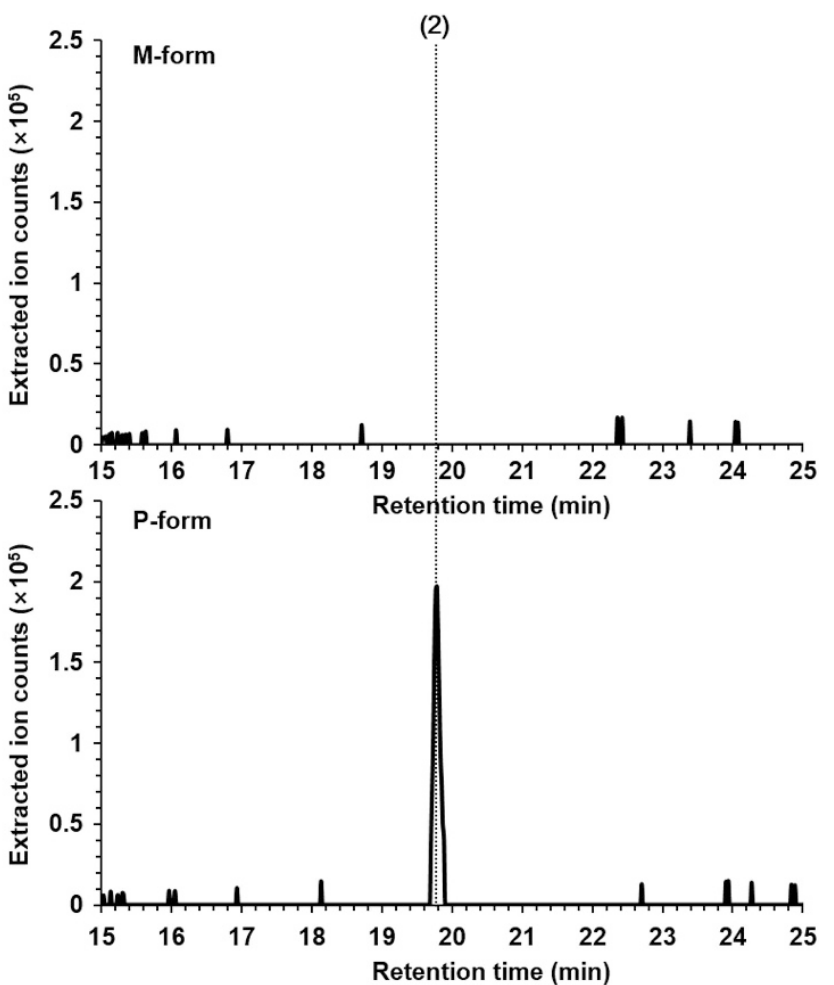

(2) from genetically engineered Photorhabdus luminescens strains locked in the the observation that lumizinone metabolites are only detected in the pathogenic P-form (Figure 4), further experiments are required to determine whether the lumizinones provide an ecological benefit to $P$. luminescens during its multipartite lifecycle.

In summary, we cultivated $P$. luminescens TT01 in a bacterial medium mimicking substrate features in natural hemolymph of the host insect G. mellonella and isolated two new pyrazinone metabolites, lumizinones A (1) and B (2), together with two linear $N$-acetylated dipeptides (3 and $\mathbf{4}$ ). The chemical structures of $\mathbf{1 - 4}$ were established by the analysis of NMR and HR-ESI-QTOF-MS spectral data. NMRbased structural characterization demonstrated that $\mathbf{1}$ and 2 share a pyrazinone ring system constituted with para-hydroxyl benzyl and isobutyl or benzyl, respectively. Compound 1 showed single-digit, $\mu \mathrm{M}$ level inhibitory activity against a model cysteine protease (calpain, $\mathrm{IC}_{50}=3.9 \mu \mathrm{M}$ ). Our results expand the chemical repertoire of the bacterial symbiont $P$. luminescens and raise intriguing new questions regarding the potential roles of pyrazinones in host-bacteria interactions.

\section{MATERIALS AND METHODS}

\section{General experimental procedures}

UV/Vis spectra were obtained on an Agilent Cary 300 UV-visible spectrophotometer (Agilent, Santa Clara, CA, USA) with a path length of $10 \mathrm{~mm}$. ${ }^{1} \mathrm{H}$ and 2D- (gCOSY, gHSQC and gHMBC) NMR spectral data were measured on an Agilent $600 \mathrm{MHz}$ NMR spectrometer (Agilent) equipped with a cold probe, and the chemical shifts were recorded as $\delta$ values (p.p.m.). Lowresolution HPLC/MS data were measured using an Agilent 6120 single quadrupole LC/MS system (Agilent). High-resolution ESI-MS data were obtained using an Agilent iFunnel 6550 QTOF instrument (Agilent) fitted with an ESI source coupled to an Agilent 1290 Infinity HPLC system (Agilent). Flash column chromatography was carried out on Waters Sep-Pak Vac $35 \mathrm{~cm}^{3}(10 \mathrm{~g})$ $\mathrm{C}_{18}$ or silica cartridges (Waters, Milford, MA, USA). The isolation of 
metabolites was performed using an Agilent Prepstar HPLC system (Agilent) with an Agilent Polaris C18-A $5 \mu \mathrm{m}\left(21.2 \times 250 \mathrm{~mm}^{2}\right)$ column (Agilent), a Phenomenex Luna C18(2) $(100 \AA) 10 \mu \mathrm{m}\left(10.0 \times 250 \mathrm{~mm}^{2}\right)$ column (Phenomenex, Torrance, CA, USA) and an Agilent Phenyl-Hexyl $5 \mu \mathrm{m}\left(9.4 \times 250 \mathrm{~mm}^{2}\right)$ column (Agilent).

\section{Cultivation and extraction}

The hemolymph-mimetic bacterial growth medium was made up of yeast extract $\left(5 \mathrm{gl}^{-1}\right)$ and the amino-acid concentrations found in the hemolymph of the insect host G. mellonella. ${ }^{11}$ Single colonies of P. luminescens TT01 first grown on Luria-Bertani agar ( $10 \mathrm{~g}^{-1}$ tryptone, $5 \mathrm{gl}^{-1}$ yeast extract, $10 \mathrm{~g} 1^{-1}$ sodium chloride, $18 \mathrm{gl}^{-1}$ agar) were inoculated into $5 \mathrm{ml}$ of the hemolymphmimetic medium and incubated at $30^{\circ} \mathrm{C}$ at 250 r.p.m. After 2 days, supernatants of cell culture broth were extracted with ethyl acetate $(2 \times 5 \mathrm{ml})$ in $14 \mathrm{ml}$ polypropylene round-bottom tubes, and the ethyl acetate-soluble layers were evaporated under reduced pressure. Crude materials were dissolved in $200 \mu \mathrm{l}$ of $100 \%$ methanol and then monitored on an Agilent 6120 single quadrupole LC/MS system (Column; Phenomenex Kinetex C18 column (Phenomenex), $250 \times 4.6 \mathrm{~mm}^{2}, 5 \mu \mathrm{m}$, flow rate; $0.7 \mathrm{ml} \mathrm{min}^{-1}$, mobile phase composition; water and acetonitrile (ACN) containing $0.1 \%$ formic acid; analysis method; $0-30 \mathrm{~min}, 10-100 \% \mathrm{ACN}$; hold for $5 \mathrm{~min}, 100 \% \mathrm{ACN}$; $1 \mathrm{~min}, 100-10 \%$ ACN). For larger-scale cultivation, a $P$. luminescens TT01 seed culture $(12 \times 5 \mathrm{ml})$ was transferred into $12 \times 1 \mathrm{~L}$ of hemolymph-mimetic medium in $4 \mathrm{~L}$ Elenmeyer flasks. After 3 days, the combined whole culture broth was extracted with $24 \mathrm{~L}$ ethyl acetate, and the organic-soluble layer was dried by rotary evaporation to yield a combined crude extract $(2.0 \mathrm{~g})$.

\section{Isolation of metabolites}

Crude materials ( $2.0 \mathrm{~g}$ ) were subjected to a Waters Sep-Pak Vac $35 \mathrm{~cm}^{3}$ (10 g) silica cartridge and separated using a step gradient with the following solvent composition: Fraction 1, hexane:EtOAc $=10: 1\left(\mathrm{v} \mathrm{v}^{-1}\right)$; Fraction 2, hexane: EtOAc $=1: 1\left(\mathrm{v} \mathrm{v}^{-1}\right)$; Fraction 3, 100\% EtOAc $\left(\mathrm{v} \mathrm{v}^{-1}\right)$; Fraction 4: EtOAC: $\mathrm{MeOH}=20: 1\left(\mathrm{vv}^{-1}\right)$; Fraction 5: EtOAc: $\mathrm{MeOH}=1: 1\left(\mathrm{vv}^{-1}\right)$; Fraction 6: $100 \% \mathrm{MeOH}\left(\mathrm{v} \mathrm{v}^{-1}\right)$. Fraction 3 containing compounds 1 and 2 was further separated over a Waters Sep-Pak Vac $35 \mathrm{~cm}^{3}(10 \mathrm{~g}) \mathrm{C}_{18}$ cartridge with the following step gradient: $20,40,60,80$ and $100 \% \mathrm{MeOH}$ in water $\left(\mathrm{v} \mathrm{v}^{-1}\right)$. Separation of the resulting $60 \% \mathrm{MeOH}$ fraction was performed using an Agilent Prepstar HPLC system with an Agilent Polaris C18-A $5 \mu \mathrm{m}$ $\left(21.2 \times 250 \mathrm{~mm}^{2}\right)$ column (flow rate $\left.10.0 \mathrm{ml} \mathrm{min}^{-1}\right)$ using a $1 \mathrm{~min}$ fraction collection time window. The combined fraction $42+43$ was fractionated using a Phenomenex Luna C18 (2) $10 \mu \mathrm{m}$ column $\left(10.0 \times 250 \mathrm{~mm}^{2}\right.$, flow rate $4.0 \mathrm{ml} \mathrm{min}^{-1}$ ) with a gradient elution from 10 to $100 \%$ aqueous $\mathrm{ACN}$, and the metabolites were finally purified over a Phenyl-Hexyl $5 \mu \mathrm{m}$ column $\left(9.4 \times 250 \mathrm{~mm}^{2}\right)$ with a general gradient system $(10-100 \%$ aqueous methanol for $30 \mathrm{~min}, 4 \mathrm{ml} \mathrm{min}^{-1}$ ). Compounds 1 and 2 were eluted at $t_{\mathrm{R}} 26.74$ and $29.31 \mathrm{~min}$, respectively.

Silica fraction 5 containing compounds 3 and $\mathbf{4}$ were subjected to a Waters Sep-Pak Vac $35 \mathrm{~cm}^{3}(10 \mathrm{~g}) \mathrm{C}_{18}$ cartridge using the following step gradient: 20, $40,60,80$ and $100 \% \mathrm{MeOH}$ in water $\left(\mathrm{v} \mathrm{v}^{-1}\right)$. The $40 \%$ methanol fraction was subsequently separated using an Agilent Prepstar HPLC system with Agilent Polaris C18-A $5 \mu \mathrm{m}\left(21.2 \times 250 \mathrm{~mm}^{2}\right.$, flow rate $\left.10.0 \mathrm{ml} \mathrm{min}^{-1}\right)$ and Phenomenex Luna C18 (2) $10 \mu \mathrm{m}$ column $\left(10.0 \times 250 \mathrm{~mm}^{2}\right.$, flow rate $\left.4.0 \mathrm{ml} \mathrm{min}^{-1}\right)$, yielding compounds $3\left(t_{\mathrm{R}} 11.64 \mathrm{~min}\right)$ and $4\left(t_{\mathrm{R}} 12.18 \mathrm{~min}\right)$, respectively.

Lumizinone A (1): Colorless solid; $\mathrm{UV}\left(\mathrm{CH}_{3} \mathrm{OH}\right) \lambda_{\max }(\log \varepsilon) 330$ (3.81), 280 (sh, 3.31), 210 (3.88) nm; ${ }^{1} \mathrm{H}$ and ${ }^{13} \mathrm{C}$ NMR spectra (see Table 1); HR-ESIQTOF-MS $[\mathrm{M}+\mathrm{H}]^{+} \mathrm{m} / z$ 259.1447 (calcd for $\mathrm{C}_{15} \mathrm{H}_{19} \mathrm{~N}_{2} \mathrm{O}_{2}, 259.1447$ ).

Lumizinone B (2): Colorless solid; $\mathrm{UV}\left(\mathrm{CH}_{3} \mathrm{OH}\right) \lambda_{\max }(\log \varepsilon) 326$ (3.64), 280 (sh, 3.31), 223, (3.83), $202(4.07) \mathrm{nm} ;{ }^{1} \mathrm{H}$ and ${ }^{13} \mathrm{C}$ NMR spectra, (see Table 1); HR-ESI-QTOF-MS $[\mathrm{M}+\mathrm{H}]^{+} \mathrm{m} / \mathrm{z} 293.1286$ (calcd for $\mathrm{C}_{18} \mathrm{H}_{17} \mathrm{~N}_{2} \mathrm{O}_{2}, 293.1290$ ).

$\mathrm{N}$-acetyl-L-leucyl-L-tyrosine (3): Colorless solid; ${ }^{1} \mathrm{H}$ NMR $\left(\mathrm{CD}_{3} \mathrm{OD}\right.$, $600 \mathrm{MHz}) \delta 7.01(2 \mathrm{H}, \mathrm{d}, J=8.5 \mathrm{~Hz}, \mathrm{H}-5$ and $\mathrm{H}-9), 6.67(2 \mathrm{H}, \mathrm{d}, J=8.5 \mathrm{~Hz}$, H-6 and H-8), $4.56(1 \mathrm{H}, \mathrm{dd}, J=8.2,5.2 \mathrm{~Hz}, \mathrm{H}-2), 4.38(1 \mathrm{H}, \mathrm{dd}, J=9.6,5.6 \mathrm{~Hz}$, H-11), $3.08(1 \mathrm{H}, \mathrm{dd}, J=14.0,5.2 \mathrm{~Hz}, \mathrm{H}-3), 2.89(1 \mathrm{H}, \mathrm{dd}, J=14.0,8.2 \mathrm{~Hz}$, $\mathrm{H}-3), 1.93$ (3H, s, H-17), 1.60 (1H, m, H-13), 1.54-1.44 (2H, m, H-12), 0.93 $(3 \mathrm{H}, \mathrm{d}, J=6.6 \mathrm{~Hz}, \mathrm{H}-14), 0.88(3 \mathrm{H}, \mathrm{d}, J=6.6 \mathrm{~Hz}, \mathrm{H}-15),{ }^{13} \mathrm{C} \mathrm{NMR}\left(\mathrm{CD}_{3} \mathrm{OD}\right.$, $125 \mathrm{MHz}) \delta 173.1$ (C-10), 173.0 (C-1), 171.9 (C-16), 155.9 (C-7), 129.9 (C-5,
C-9), 127.3 (C-4), 114.6 (C-6, C-8), 53.5 (C-2), 51.4 (C-11), 40.1 (C-12), 35.9 (C-3), 24.3 (C-13), 21.7 (C-14), 20.8 (C-17), 20.5 (C-15); HR-ESI-QTOF-MS $[\mathrm{M}+\mathrm{H}]^{+} \mathrm{m} / z 337.1763$ (calcd for $\mathrm{C}_{17} \mathrm{H}_{25} \mathrm{~N}_{2} \mathrm{O}_{5}, 337.1763$ ).

$\mathrm{N}$-acetyl-L-leucyl-L-methionine (4): Colorless solid; ${ }^{1} \mathrm{H}$ NMR $\left(\mathrm{CD}_{3} \mathrm{OD}\right.$, $600 \mathrm{MHz}) \delta 4.49(1 \mathrm{H}, \mathrm{dd}, J=9.0,4.4 \mathrm{~Hz}, \mathrm{H}-2), 4.38(1 \mathrm{H}, \mathrm{dd}, J=9.8$, $5.5 \mathrm{~Hz}, \mathrm{H}-7), 2.56$ (1H, ddd, $J=13.8,9.0,5.0 \mathrm{~Hz}, \mathrm{H}-4), 2.50(1 \mathrm{H}, \mathrm{m}, \mathrm{H}-4)$, $2.13(1 \mathrm{H}$, dddd, $J=13.7,9.0,7.2,4.5 \mathrm{~Hz}, \mathrm{H}-3), 2.06(3 \mathrm{H}, \mathrm{s}, \mathrm{H}-5), 1.96(3 \mathrm{H}, \mathrm{s}$, $\mathrm{H}-13), 1.95$ (1H, m, H-3), 1.69 (1H, m, H-9), 1.57 (2H, m, H-8), $0.96(3 \mathrm{H}, \mathrm{d}$, $J=6.6 \mathrm{~Hz}, \mathrm{H}-10), 0.92(3 \mathrm{H}, \mathrm{d}, J=6.6 \mathrm{~Hz}, \mathrm{H}-11),{ }^{13} \mathrm{C} \mathrm{NMR}\left(\mathrm{CD}_{3} \mathrm{OD}\right.$, $125 \mathrm{MHz}) \delta 173.7$ (C-1), 173.4 (C-6), 171.7 (C-12), 51.5 (C-2), 51.7 (C-7), 40.3 (C-8), 31.0 (C-3), 29.6 (C-4), 24.3 (C-9), 21.8 (C-10), 20.8 (C-13), 20.4 (C-11), 13.7 (C-5); HR-ESI-QTOF-MS $[\mathrm{M}+\mathrm{H}]^{+} \mathrm{m} / \mathrm{z} 305.1531$ (calcd for $\left.\mathrm{C}_{13} \mathrm{H}_{25} \mathrm{~N}_{2} \mathrm{O}_{4} \mathrm{~S}, 305.1535\right)$.

\section{Absolute configuration determination of amino acids}

Standard D- and L-amino acids (leucine, methionine and tyrosine) were purchased from Sigma-Aldrich (St Louis, MO, USA). Compounds $3(0.5 \mathrm{mg})$ and $4(0.3 \mathrm{mg})$ were hydrolyzed in $500 \mu \mathrm{l}$ of $6 \mathrm{~N} \mathrm{HCl}$ at $110^{\circ} \mathrm{C}$ for $1 \mathrm{~h}$, and the reaction mixture was dried in vacuo or under purging of nitrogen gas. The hydrolysate was dissolved in distilled water and completely dried for $24 \mathrm{~h}$ in a Genevac HT-4X Evaporation System to remove excess acid. The hydrolyzed materials and standard amino acids were treated with $50 \mu \mathrm{l}$ of a solution of $N_{\alpha^{-}}$ (2,4-dinitro-5-fluorophenyl)-L-alaninamide (FDAA) $\left(10 \mathrm{mg} \mathrm{ml}^{-1}\right.$ in acetone) followed by the addition of $100 \mu \mathrm{l}$ of $1 \mathrm{~N} \mathrm{NaHCO}_{3}$. The reaction mixture was heated at $80^{\circ} \mathrm{C}$ for $3 \mathrm{~min}$ and quenched with $50 \mu \mathrm{l}$ of $2 \mathrm{~N} \mathrm{HCl}$. The derivatized materials were then diluted to $300 \mu \mathrm{l}$ with $50 \%$ aqueous ACN for LC/MS analysis. Ten microliters of the materials was analyzed by the single quadrupole LC/MS system equipped with a Phenomenex Kinetex C18 (100 $\AA$ ) $5 \mu \mathrm{m}$ $\left(4.6 \times 250 \mathrm{~mm}^{2}\right)$ column using a flow rate $\left(0.7 \mathrm{ml} \mathrm{min}^{-1}\right)$ and a solvent system of water and $\mathrm{ACN}$ containing $0.1 \%$ formic acid. The retention times of derivatized amino acids were as follows: gradient: 0-40 $\mathrm{min}, 20-60 \% \mathrm{ACN}, \mathrm{L}-$ Leu $26.45 \mathrm{~min}$, D-Leu $30.17 \mathrm{~min}$; gradient: 0-30 min, 20-35\% ACN, L-Tyr $11.92 \mathrm{~min}$, D-Tyr $12.06 \mathrm{~min}$; gradient: $0-40 \mathrm{~min}, 40-100 \%$ ACN; L-Met $7.25 \mathrm{~min}$ and D-Met $8.46 \mathrm{~min}$.

\section{Comparative chemical analysis of $\mathrm{M}$ - and $\mathrm{P}$-form phenotypic variants}

Genetically locked M- and P-form P. luminescens were individually cultivated on Luria-Bertani agar plates at $30^{\circ} \mathrm{C}$ for $48 \mathrm{~h}$. Single colonies were inoculated into $5 \mathrm{ml}$ hemolymph-mimetic medium and cultivated under aerobic conditions in a shaking incubator $\left(30^{\circ} \mathrm{C}, 250\right.$ r.p.m.). After $72 \mathrm{~h}$, the culture broths were centrifuged $(20 \mathrm{~min}, 3000$ r.p.m.), and the supernatants were then extracted with ethyl acetate $(2 \times 5 \mathrm{ml})$. The organic materials were dried under reduced pressure on a Genevac HT-4X Evaporation System (Genevac Inc, Gardiner, NY, USA) for $2 \mathrm{~h}$. The samples were resuspended in $200 \mu \mathrm{l}$ methanol, and $2 \mu \mathrm{l}$ of sample was injected for HR-ESI-QTOF-MS analysis (Column; Phenomenex Kinetex C18 column, $250 \times 4.6 \mathrm{~mm}^{2}, 5 \mu \mathrm{m}$, flow rate; $0.7 \mathrm{ml} \mathrm{min}^{-1}$, mobile phase composition; water and ACN containing $0.1 \%$ formic acid; analysis method; 0-30 min, 5-100\% ACN; hold for $5 \mathrm{~min}, 100 \%$ ACN; $1 \mathrm{~min}, 100-5 \% \mathrm{ACN})$. Extracted ion count chromatograms were extracted with $\mathrm{m} / \mathrm{z} 259.1447$ corresponding to lumizinone A and $\mathrm{m} / \mathrm{z}$ 293.1286 corresponding to lumizinone B with a 10 p.p.m. mass window.

\section{Calpain protease inhibitory assay}

Calpain 1 (human plasma) was purchased from Sigma-Aldrich. The luminescence assay was performed using the Calpain-Glo Protease Assay (Promega, Madison, WI, USA) according to the manufacturer's instructions. Luminescence was monitored using an Envision Multimode Plate Reader (PerkinElmer, Waltham, MA, USA). Stock solutions of compounds were prepared in $10 \%$ dimethyl sulfoxide and stored at $-20{ }^{\circ} \mathrm{C}$ before use, and the compounds and enzymes were resuspended in a buffer solution composed of $10 \mathrm{mM}$ HEPES ( $\mathrm{pH}$ 7.2), 10 mм dithiothreitol, 1 mм EDTA and 1 mм EGTA. The compounds were serially diluted with an initial concentration of $200 \mu \mathrm{M}$ across the row of a 96-well plate in triplicate. 


\section{CONFLICT OF INTEREST}

The authors declare no conflict of interest.

\section{ACKNOWLEDGEMENTS}

Our work on the discovery of bioactive metabolites from bacterial symbionts was supported by the National Institutes of Health (National Cancer Institute grant 1DP2-CA186575 and National Institute of General Medical Sciences grant R00-GM097096). We also gratefully acknowledge support from the Searle Scholars Program (grant 13-SSP-210) and the Damon Runyon Cancer Research Foundation (grant DRR-39-16).

1 Bode, H. B. Entomopathogenic bacteria as a source of secondary metabolites. Curr Opin. Chem. Biol. 13, 224-230 (2009).

2 Brachmann, A. O. \& Bode, H. B. in Yellow Biotechnology I (ed. Vilcinskas, A.) 123-155 (Springer, Berlin, Germany, 2013).

3 Vizcaino, M. I., Guo, X. \& Crawford, J. M. Merging chemical ecology with bacterial genome mining for secondary metabolite discovery. J. Ind. Microbiol. Biotechnol. 41, 285-299 (2014).

4 Murfin, K. E. et al. Nematode-bacterium symbioses - cooperation and conflict revealed in the "omics" age. Biol. Bull. 223, 85-102 (2012).

5 Waterfield, N. R., Ciche, T. \& Clarke, D. Photorhabdus and a host of hosts. Annu. Rev. Microbiol. 63, 557-574 (2009).

6 Somvanshi, V. S. et al. A single promoter inversion switches Photorhabdus between pathogenic and mutualistic states. Science 337, 88-93 (2012).

7 Eleftherianos, I. et al. An antibiotic produced by an insect-pathogenic bacterium suppresses host defenses through phenoloxidase inhibition. Proc. Natl Acad. Sci. USA 104, 2419-2424 (2007).

$8 \mathrm{Hu}, \mathrm{K}$. \& Webster, J. M. Antibiotic production in relation to bacterial growth and nematode development in Photorhabdus-Heterorhabditis infected Galleria mellonella larvae. FEMS Microbiol. Lett. 189, 219-223 (2000).

9 Joyce, S. A. et al. Bacterial biosynthesis of a multipotent stilbene. Angew. Chem. Int Ed. 47, 1942-1945 (2008)

10 Crawford, J. M., Portmann, C., Zhang, X., Roeffaers, M. B. \& Clardy, J. Small molecule perimeter defense in entomopathogenic bacteria. Proc. Natl Acad. Sci. USA 109, 10821-10826 (2012)
11 Crawford, J. M., Kontnik, R. \& Clardy, J. Regulating alternative lifestyles in entomopathogenic bacteria. Curr. Biol. 20, 69-74 (2010).

12 Fischer-Le Saux, M., Viallard, V., Brunel, B., Normand, P. \& Boemare, N. E. Polyphasic classification of the genus Photorhabdus and proposal of new taxa: $P$. luminescens subsp. luminescens subsp. nov., P. luminescens subsp. akhurstii subsp. nov., $P$. luminescens subsp. laumondii subsp. nov., $P$. temperata sp. nov., $P$. temperata subsp. temperata subsp. nov. and P. asymbiotica sp. nov. Int. J. Syst. Bacteriol. 49(Part 4), 1645-1656 (1999).

13 Zimmermann, M. \& Fischbach, M. A. A family of pyrazinone natural products from a conserved nonribosomal peptide synthetase in Staphylococcus aureus. Chem. Biol. 17, 925-930 (2010).

14 Alvarez, M. E. et al. Phevalin, a new calpain inhibitor, from a Streptomyces sp. J. Antibiot. 48, 1165-1167 (1995).

15 Marfey, P. Determination of D-amino acids. II. Use of a bifunctional reagent, 1 , 5-difluoro-2, 4-dinitrobenzene. Carlsberg Res. Commun. 49, 591-596 (1984).

16 Yanari, S. \& Mitz, M. A. The mode of action of pancreatic carboxypeptidase. II. The affinity of carboxypeptidase for substrates and inhibitors1. J. Am. Chem. Soc. 79 1154-1158 (1957).

17 Wyatt, M. A., Mok, M. C., Junop, M. \& Magarvey, N. A. Heterologous expression and structural characterisation of a pyrazinone natural product assembly line. ChemBioChem. 13, 2408-2415 (2012).

18 Wyatt, M. A. et al. Staphylococcus aureus nonribosomal peptide secondary metabolites regulate virulence. Science 329, 294-296 (2010).

19 Secor, P. R. et al. Phevalin (aureusimine B) production by Staphylococcus aureus biofilm and impacts on human keratinocyte gene expression. PLOS ONE 7, e40973 (2012).

20 Duchaud, E et al. The genome sequence of the entomopathogenic bacterium Photorhabdus luminescens. Nat. Biotechnol. 21, 1307-1313 (2003).

21 Wilkinson, P. et al. Comparative genomics of the emerging human pathogen Photorhabdus asymbiotica with the insect pathogen Photorhabdus luminescens. BMC Genomics 10, 1 (2009).

22 Sato, K. \& Kawashima, S. Calpain function in the modulation of signal transduction molecules. Biol. Chem. 382, 743-751 (2001).

23 Goll, D. E., Thompson, V. F., Li, H., Wei, W. \& Cong, J. The calpain system. Physiol. Rev. 83, 731-801 (2003).

24 Saito, K., Elce, J. S., Hamos, J. E. \& Nixon, R. A. Widespread activation of calciumactivated neutral proteinase (calpain) in the brain in Alzheimer disease: a potentia molecular basis for neuronal degeneration. Proc. Natl Acad. Sci. USA 90, 2628-2632 (1993).

25 Paquette, N. et al. Caspase-mediated cleavage, IAP binding, and ubiquitination: linking three mechanisms crucial for Drosophila NF-kappaB signaling. Mol. Cell 37, 172-182 (2010).

Supplementary Information accompanies the paper on The Journal of Antibiotics website (http://www.nature.com/ja) 